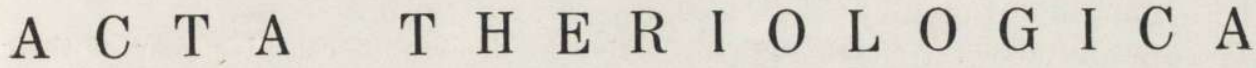 VOL. VIII, 7: 115-124.

\section{Morphology of the Adrenal Cortex of Sorex araneus Linnaeus, 1758 During the Liie Cycle}

\author{
Moriologia kory nadnerczy ryjówki aksamitnej, \\ Sorex araneus Linn a e s, 1758, w cyklu życiowym
}

[With 2 Figs. \& 2 Plates]

\section{INTRODUCTION}

The common shrew, Sorex araneus L in na e us, 1758, has formed the subject of much research, both biological and histomorphological. The biology of the shrew was described a.o. by Dehnel $(1940 ; 1952)$ and also Borowski \& Dehnel (1952). Tarkowski $(1956 ; 1957)$ investigated the reproduction and embryonic mortality of the shrew, while its sexual apparatus was dealt with by B ra m bell (1935), W ols k a (1952), P ucek (1960). Variations in certain of the endocrinal glands during the life cycle have also been investigated. The histomorphological variations in the thyroid glands of the shrew during the life cycle are described in the paper by Dzierżkray-Rogalska (1952) and the thymus gland is described in the article by $\mathrm{Baz}$ a $\mathrm{n}$ (1952).

Research on variations in the organs of animals during the life cycle would seem to be essential on account of the possibility of connecting the biology of the animal with physiological functions, which in turn gives a complete picture of the life of the given animals.

The subject of my paper is formed by investigation of the variations which take place in the adrenal glands of the shrew during its life cycle. As these changes are closely connected with the age and function of the sexual apparatus of the shrew. I have included a few details on the life of this animal.

The first to distinguish age classes in the shrew was $\mathrm{Ja} \mathrm{cks}$ on (1928). D e h n e 1 (1949), however, considered the classification made by $\mathrm{Jacks}$ on as slightly schematic, not taking into account the specific anatomical and physiological properties of Soricidae, and therefore used as simplified division into classes, which would seem to be closer to nature. He takes period of attainment of sexual maturity by the shrew as the critical point. This, under Polish climatic conditions, usually takes place in April of the year following their birth. Up to this period, irrespective of their calendar age, Dehnel terms the shrews "young adults", that is animals 
not sexually active. Animals sexually active in the second calendar year of their lives are termed "old adults". The age division described above will be used in describing the material dealt with in the present article.

Sexually mature males are encountered in Białowieża as from April (B or ow$\mathrm{ski} \& \mathrm{Dehnel}, 1952)$, oestrus in females occurs about ten days later than in males. Pregnancy lasts twenty days, the young spend twenty-three days in the nest (D e hnel, 1952). The sexual activity of shrews ends in October (T a r k owski, 1957). Dehnel (1949) considered that theoretically the greatest age which the shrew can attain in Poland is eighteen months. Borowski \& Dehnel (1952) state that young shrews do not as a rule mature sexually in the first calendar year of life. About $2 \%$ of the young females mature sexually and become pregnant in the first calendar year of their lives ( $\mathrm{P} \mathrm{u} \mathrm{c} \mathrm{e} \mathrm{k,} \mathrm{1960).} \mathrm{Under} \mathrm{laboratory} \mathrm{conditions,} \mathrm{with}$ intensive feeding of the animals on a diet rich in vitamins, sexual maturation as a rule takes place in the first calendar year of life.

Many papers are encountered in literature on the adrenal glands, describing the results of both morphological and histochemical research. In the latter field $\mathrm{H}$ un \& H u n t (1959) dealt with the glycogen content in the adrenal glands of rats during the life cycle. Rods (1958) investigated the presence of desoxyribonuclein acid in the adrenal glands of white rats.

Investigation was also made of the dependence of the adrenal gland on other endocrinal glands, for example the connection between the adrenal and parathyroid giands was described by, inter alia, M a r th a \& L e o $\mathrm{n}$ a r d (1946). N a r b u t t et al. (1961) described the effect of experimental hypofunction of the thyroid gland on the weight and function of the adrenal gland in rats.

Investigation was also made of the dependence of the adrenal glands on other sex glands, and in particular the behaviour of zone $X$ (D e los t, 1955; 1956; 1957; Sakiz, 1959; Wiśniewski, 1959). Zone $X$, called by different authors the zone of acidophilic cells, transitional embryonic zone, androgenic zone, juxta-medullar zone, described for the first time by M a s i \& Tam ura (1926), has formed the object of research both in humans (G rollma n, 1936; Pawlikowski, 1951; W o ły ń s ka, 1956) and in animals (B a chmann, 1954; Delos t, 1955; 1956; 1957; S a k i z, 1959).

I have not as far encountered in literature reports on the variations in the adrenal glands of Soricidae during the life cycle, and on this account I have dealt with this problem in relation to the common shrew.

\section{MATERIAL AND METHODS}

The material came from the Białowieża National Park, and was collected in 1953, $1954,1957,1958,1959$ and 1960 . The animals were caught on permanent capture areas by means of metal cylinders. The capture methods used have been described in the article by Borowski \& Dehnel (1952).

The captured animals were weighed, body length measured, and the testes measured in the case of males. The adrenal glands were fixed in Bouin fluid and in formalin, and dipped in paraffin. Specimens $5 \mu$ thick were cut in series, stained with Azan, fuchsin acc. to Masson and haematoxylin and eosin. A total of 138 animals, consisting of 73 males and 65 females, were used for the investigations. The animals were divided into two groups (using the division given by $\mathrm{De} h \mathrm{nel}$, 1949) that is into young adults and old adults. There were both pregnant individuals and lactating individuals, which were simultaneously pregnant, among the 
femaies, but there were no lactating females which were not pregnant. The breadth of the zones in the adrenal cortex was measured by means of a micrometric lens.

The subject of the work carried out and the material for it were received from the late Professor August De hne l, Mammals Research Institute, Polish Academy of Sciences.

\section{RESULTS OF INVESTIGATIONS}

\section{Young adult males}

The youngest animals are encountered in June. During this period the adrenal cortex of males consists of three zones (Fig. 1, Plate IX), the zona glomerulosa, which is formed of two to three zones of cells, is situated most peripherally immediately under the capsule of connective tissue. The cytoplasm of these cells is of a foam-like structure. The nuclei of the cells are round, vesicular with a small amount of chromatin, and stain only faintly (Fig. 2, Plate IX).

The second zone is formed by zona fasciculata, and it is far thicker than the first. It is formed of fairly large oval cells with dense acidophilic cytoplasm (Fig. 2). There is connective tissue between the cells. Two kinds of cellular nuclei can be distinguished in this zone: nuclei with a small amount of chromatin, but even so staining more intensively than the nuclei of zona glomerulosa, and nuclei with a large amount of chromatin, staining deeply with alkaline staining agents.

Between the second and third zones there are sometimes small cells with compact, uniform, strongly acidophilic cytoplasm (Fig. 3, Plate IX), distinctly separating the second zone from the third one. This kind of cell is also encountered among the cells of the zona fasciculata.

The third zone of the adrenal cortex, the zona reticularis, consists of an external and internal part. The first of these is formed of cells far smaller than the cells in zona fasciculata (Fig. 4, Plate IX). The cytoplasm of the cells is less chromatinous. Two kinds of nucleus are also encountered but they are smaller than those in the zona fasciculata. The thin internal part of the zona reticularis lies most centrally, and is formed of larger acidophilic cells with larger nuclei than the cells of the external part of zona reticularis. There are numerous blood vessel between the cells of zona reticularis. The thickest zone of the cortex of the animals described in the zona reticularis, the thinnest - zona glomerulosa.

In July, August and September the adrenal cortex of young adult males is similar in structure to that in June, and during these months the zona reticularis continues to be the thickest. From June to September the zonae fasciculata and reticularis thicken, the zona glomerulosa remains unchanged. As from October considerable reduction of the adrenal glands is visible, the thickness of the fasciculata and reticularis decreasing, and 
as from November the boundaries between the zones become obliterated. In November, December, January and February the adrenal cortex is far thinner than in the summer months (Fig. 1, Plate X). During this time no cells of the internal part of zona reticularis can be seen at all. In March the cortex again thickens; the zonae fasciculata and reticularis enlarge.

\section{Old adult males}

Sexually mature males are encountered as early as in March. At this time the adrenal cortex does not exhibit a distinct zonal structure. Zona reticularis is very narrow and does not exhibit any distinct line of demarcation with the zona fasciculata. In April the adrenal cortex thickens slightly. In certain individuals the presence of cells of the internal part of zona reticularis can be seen distinctly from the side of the meduila (Fig. 2, Plate X). These cells are encountered in old adult males only in April. In April, May, June and July, the thickness of zona fasciculata hardly varies at all, while zona glomerulosa thickens slightly (Diagram 1, A).

\section{Young adult females}

The youngest females, like the males, fall into the traps in June. The adrenal cortex of young females is similar in structure to the adrenal cortex in young males during the same period. The external zone of the cortex is composed of zona glomerulosa formed of two to three rows of cells. It must be emphasised that individual variations in the thickness of this zone occur in different animals. The second zone of the cortex is zona fasciculata, which does not differ morphologically from the zona fasciculata of males. I would only say that this zone is thicker in females. Zona reticularis also is thicker in females, and in addition has no cells of the internal part. The thickest zone of the adrenal cortex in young adult females is zona reticularis, which occupies more than half the thickness of the cortex. This state of the cortex is maintained until September, as from which month we can observe considerable reduction in the thickness of the cortex at the expense of zonae fasciculata and reticularis, zona glomerulosa remaining unchainged. The thinnest cortex, as in the case of males, occurs in January and February (Fig. 2, Plate IX).

\section{Pregnant young adult females}

Females are sporadically encountered which have matured sexually in the first calendar year of life. In these females the adrenal cortex is formed in almost the same way as the cortex in young females which are not pregnant. The only difference occurring is that cells of the internal part of zona reticularis appear bordering on the adrenal medulla. These 
cells are larger than the cells in the external part of zona reticularis, and their cytoplasm is more acidophilic (Fig. 3, Plate X).

In zonae fasciculata and reticularis cellular nuclei of different size are encountered.

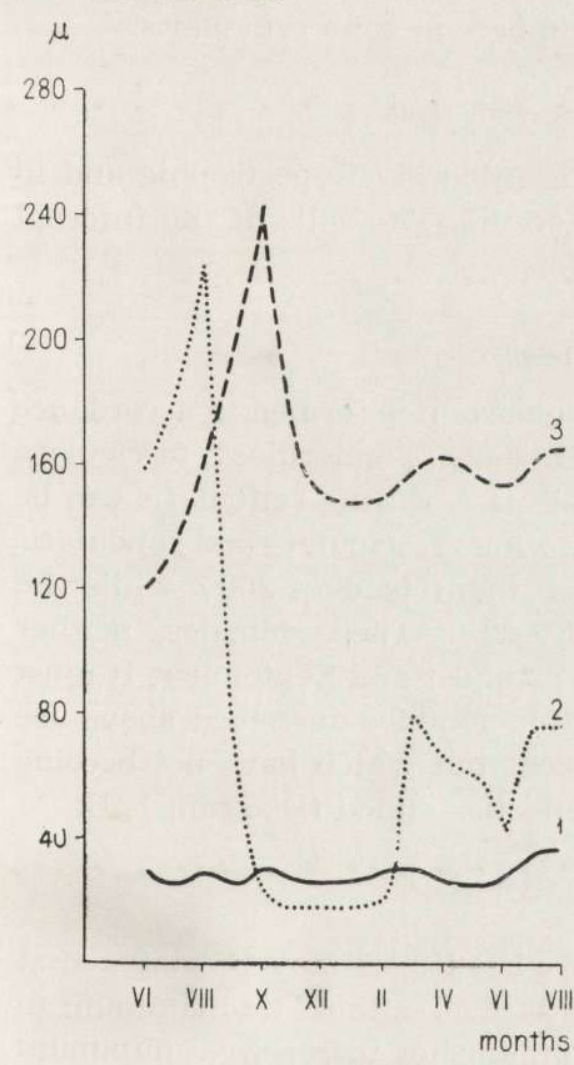

A. MALES

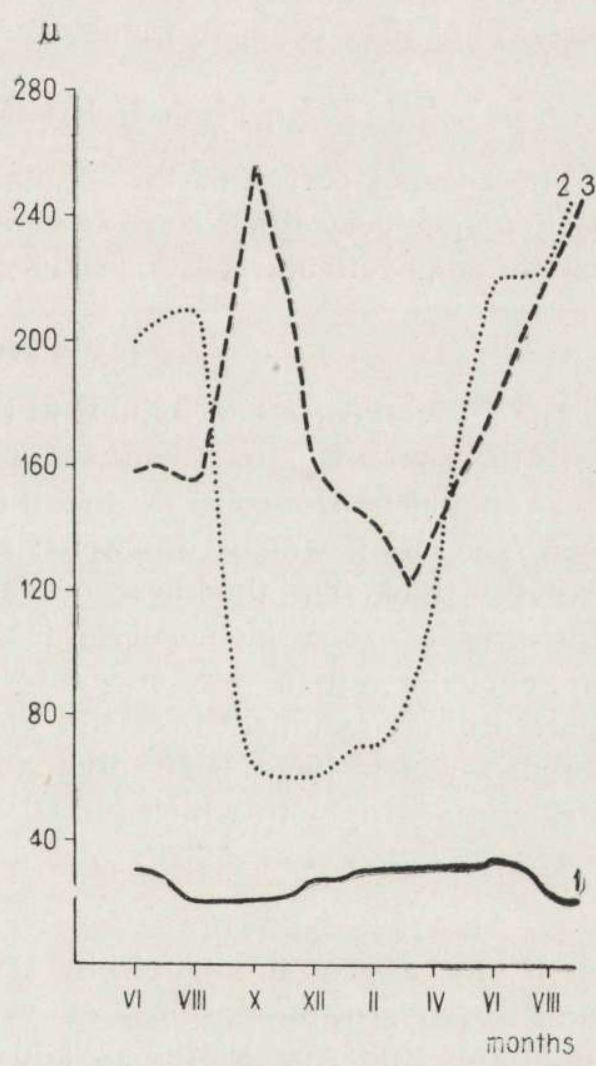

B. FEMALES

Diagram 1. Seasonal changes of thickness of various zones of the adrenal cortex in the Common shrew, Sorex araneus L.

Axis X - particular months of shrews' life cycle, Axis Y - thickness in microns. 1 - zona glomerulosa, 2 - zona reticularis, 3 - zona fasciculata.

\section{Pregnant old adult females}

Zona glomerulosa and fasciculata of the adrenal cortex in pregnant females from the old adult group, caught from May to September, are only faintly separated from each other. The thickest zone of the cortex is zona reticularis, consisting of an external and an internal part. The external part of zona reticularis is formed of far smaller cells than those in zona fasciculata. There are larger cells, oval in shape with light- 
coloured cytoplasm and large round nuclei between these cells. The cells of the internal part of zona reticularis bordering on the adrenal medulla are clearly visible. In general considerable growth of the adrenal cortex is observed. There are very numerous blood cells throughout the whole cortex, but they occur in the greatest numbers in zona reticularis.

\section{Pregnant, lactating old adult females}

The adrenal cortex of these animals is intensely hypertrophic and in particular a very thick zona reticularis occurs. The cells of the internal part of zona reticularis are clearly visible.

\section{Old adult females}

The adrenal cortex of animals in this age group is formed in accordance with the general plan. It consists of three zones: glomerulosa, fasciculata and reticularis. No cells of the internal part of zona reticularis can be seen. The fact is worthy of emphasis that zonae fasciculata and reticularis are very thick. The thickness of each of them is over $200 \mu$ while the thickness of zona glomerulosa is hardly $22 \mu$. These females, neither pregnant nor nursing, are encountered in August and September. It must therefore be assumed that the old adult females described above are females which have been pregnant once, but which have not become pregnant again, or in which sexual activity has ended (Diagram 1, B).

\section{DISCUSSION}

On the basis of the article by Dehnel (1949) it may be stated that the size (weight, dimensions) of young shrews attains its maximum in June, July and August, then gradually diminishes to reach a minimum during the winter months. In March body weight and length increases, and in April the body begins to grow enormously. Dehnel considers that the sudden jump in the growth of shrews in April is probably connected with, inter alia, the attainment of sexual maturity.

W o l s k a (1952) in investigating the testes of males, observed that the smallest dimensions of the testes of young males are encountered in January. This authoress is of the opinion that sexual maturescence occurs suddenly and sharply over a very short period at the end of March, in the second calendar year of life of shrews. The testes of old adult males increase in size from Aprii to August, while senile regression of the gonads is observed as from September.

In the same way the thymus gland investigated by $\mathrm{B}$ a $\mathrm{z}$ a $\mathrm{n}$ (1952) exhibits transition to the rudimentary state during the autumn and winter months, for four months before the sexual maturescence period. 
On the basis of the above observations it may be said that shrews pass through a period of "winter depression" expressed by a decrease in body length, body weight, reduction in height of skull (D e h n e l, 1949), and weight of the brain (B i e lak \& P u cek, 1960), and involution of the thymus (B a z a n, 1952).

Similar changes connected with the "winter depression" period can be observed in the adrenal glands of shrews.

The adrenal glands of the youngest males and females exhibit almost identical structure. In June, July, August and in part of September the morphological picture of the adrenal cortex of these animals undergoes no change. As from October a decrease in thickness of the adrenal cortex can be observed (in particular of zona reticularis and partly of zona fasciculata) in both sexes. The thinnest cortex is encountered in January and February. Zona glomerulosa remains unchanged throughout the whole period. It must be emphasised that these animals are still sexually immature during this period.

The above observations agree with the results of investigations of the weight of the adrenal glands of shrews ( $\mathrm{P} \mathrm{u} \mathrm{cek}$, in litt.). This author found that the lowest weight of the adrenal glands occurs during the winter months.

My observation on the disappearance of zona reticularis ${ }^{1}$ ) in male sexually immature shrews would not, however, agree with those made by Masui \& Tamura (1926) and Wiśniewski (1959). These authors state that in male white mice zone $X$ does not disappear until the animals attain sexual maturity. It may be assumed that the lack of agreement between the above observations is the result of specific difference between the animals. The growth of zona reticularis which I observed in pregnant females and in females both pregnant and simultaneously nursing their previous litter is not confirmed by the information given by Delost (1957), who states that in females of Sorex araneus zone $X$ disappears, in the same way as in mice, during the first pregnancy. On the other hand this same author $(1955 ; 1956)$ considers that in Microtinae zone $X$ not only does not disappear, but remains and grows both during the lactation and also after several pregnancies in old females, and this agrees with my own observations. The author suggests that adrenal function in these animals is probably connected with the pituitary gland. In the winter, when the pituitary gland produces less hormones, the adrenal cortex exhibits involution. In the spring the intensified activity

1) I must emphasise that the question of the nomenclature of the deeper zones of the adrenal cortex has not as yet been definitly established. Some authors term the third zone - zona reticularis - layer $X$ (D e los t), while others distinguish in zona reticularis an external and internal part, this latter being termed layer $X$ or the fourth zone or zona juxta-medulla. 
of the pituitary gland influences the stimulation and development of the adrenal glands. Delost (1956) also puts forward the hypothesis, that zona glomerulosa is not dependent on the pituitary gland. On the basis of my observations $\mathrm{I}$ am inclined to accept D e los t's concept as to the corriection between the adrenal glands and the pituitary glands, since during the winter period, when the pituitary gland is less active, I observed involution of zonae fasciculata and reticularis of the adrenal glands of the shrew. In addition the fact which I observed that zona glomerulosa in young shrews of both sexes is not subject to seasonal changes, would vear out the statement that this zone is not dependent on the pituitary gland.

We can connect the involution of the adrenal cortex of the common shrew during the winter with the involution of the thymus gland, with a decrease in body weight, with reduction in the height of the skul (D e h nel, 1949), and with decrease in size of the testes. It may be considered that these processes taking place in the adrenal glands have a uniform basis, that they are caused by the same factors, which cause the occurrence of seasonal variations in the whole complex of morphological and physiological indices in shrews.

\section{SUMMARY}

1. The adrenal cortex in male and female shrews is of stratiform structure and consists of zona glomerulosa, zona fasciculata and reticularis.

2. Zona reticularis of young adult and old adult males in April and also of pregnant, and of pregnant and simultaneously lactating females, consists of an external and internal part (fourth layer, juxta-medullar layer).

3. Growth of the whole zona reticularis occurs in pregnant females and in females pregnant and simultaneously lactating.

4. The thickness of the adrenal cortex in shrews is subject to seasonal varietions: from June to September the cortex of young adult males and females thickens, from October onwards it undergoes involution at the expense of zona fasc:culata and reticularis, attaining its minimum in January and February. In old aciults the thickness of the above zones increases slightly in males and very strongly in females, which are sexually active. It then attains \pm the same thickness as it does in young individuals. Zona glomerulosa does not exhibit any seasonal variations.

Acknowledgments: It is my pleasant duty to thank Docent Helena Le wi ńs ka, M. D., Head of the Department of Histology and Embryology of the Białystck Medical Academy, for her critical remarks and assistance during the preparation of this paper.

\section{REFERENCES}

1. B a chmann, R. W. \& Möllendorff, W., 1954: Hbd. d. mikr. Anat. d. Mensch. Die Nebenniere, Berlin.

2. B a z a n, I., 1952: Zmiany morfohistologiczne grasicy u Sorex araneus L. w cyklu życiowym. Ann. Univ. M. Curie-Skłodowska, Sect. C, 7, 5: 253-304. Lublin. 
3. Bielak, T. \& Pucek, Z., 1960: Seasonal changes in the brain weight of the Common shrew (Sorex a. araneus L in n a e us, 1758). Acta theriol., 3, 13: 297300. Białowieża.

4. Borowski, S. \& Dehne 1, A., 1952: Materiały do biologii Soricidae. Ann. Univ. M. Curie-Sklodowska, Sect. C, 7, 6: 305-448.

5. B r a m be 11, R. F. W., 1935: Reproduction in the Common Shrew (Sorex araneus Linnaeus). I. The Oestrus Cycle of the Female. Phil. Trans. Roy. Soc. Lond., 225: 1-49.

6. De hne 1, A., 1949: Badania nad rodzajem Sorex L. Ann. Univ. M. Curie-Skłodowska, Sect. C, 4, 2: 17-102.

7. De hne l, A., 1952: The biology of breeding of Common shrew, S. araneus L. in laboratory conditions. Ann. Univ. M. Curie-Skłodowska, Sect. C, 6, 11: 359-376.

8. Delost, P., 1955: Nouvelles données sur la zona X surrenalienne. J. Physiol., 47: $164-170$.

9. Delos t, P., 1956: La fonction sexuelle de la cortico-surrénale. Récents Progrès en Physiologie, 47-74. Publication de la Chaire de Physiologie générale de la Soroonne.

10. Delost, P., 1957: Recherches sur le cortex surrénal et la zona X des Musaraignes (Sorex araneus L. et Crocidura russula H.). C. R. Soc. Biol. 151, 3: 484487.

11. D zi er ży kra y - R o ga l ska, I., 1952: Zmiany histomorfologiczne tarczycy S. a. araneus L. w cyklu życiowym. Ann. Univ. M. Curie-Skłodowska. Sect. C, 7, 4: 213-252.

12. G r o $11 \mathrm{~m}$ a n, A., 1936: The Adrenals. Baltimore.

13. H unt, T. E. \& H un t, E. A., 1959: Glycogen in the adrenal gland of rats at different ages. Anat. Rec., 133, 3: 537-551.

14. J a cks o n, H. H. T., 1928: A taxonomic review of the American longtailed Shrews. North Americana Fauna. Washington, 51.

15. M a r th a, F. \& L e on a r d, M. D., 1946: Chronic idiopathic hypoparathyroidism with superimposed Addison's disease in a child. J. Clin. Endocr., 6: 493-495.

16. M a sui, K. \& T a m ura, Y., 1926: acc. to Wiśniewski, 1959.

17. Narbut, B., Romer, T., Buntner, B. \& Grabski, J., 1961: Wplyw doświadczalnej niedoczynności tarczycy na wagę i czynność nadnerczy szczurów. Endokr. pol., 12: 363-379.

18. P a w li k ow ski, T., 1951: Pozapłodowy rozwój nadnercza u człowieka. Endokr. pol., 2: 185-191.

19. Pucek, Z., 1960: Sexual maturation and variability of the reproductive system in young shrews (Sorex L.) in the first calendar year of life. Acta theriol., 3, 12: $269-296$.

20. Rods, H., 1958: Desoxyribonucleic acid content of the nuclei in the adrenal cortex of the white rat. Nature, 182: 873-876.

21. S a kiz, E., 1959: Action sur la zona $\mathrm{X}$ surrenalienne de la souris, de la corticostimuline on d'une agression. C. R. Soc. Biol., 153, 3: 405-407.

22. T a r k ow ski, A. K., 1956: Badania nad rozrodem i śmiertelnością zarodkową u ryjówki aksamitnej (Sorex araneus L.). Część I. Regresja płodów. Ann. Univ. M. Curie-Skłodowska, Sect. C, 9, 9: 387-429.

23. T a rkowski, A. K., 1957: Badania nad rozrodem i śmiertelnością zarodkową u ryjówki aksamitnej (Sorex araneus L.). Część II. Rozród w warunkach naturalnych. Ann. Univ. M. Curie-Skłodowska, Sect. C, 10, 8: 177-244.

24. Wiśniewski, L., 1959: Wpływ usunięcia gonad na zachowanie się i obraz morfologiczny warstwy X u myszy białej. Folia morphol., 10: 77-82. 
25. W o Is k a, J., 1952: Rozwój aparatu płciowego Sorex araneus L. w cyklu życio-owym. Ann. Univ. M. Curie-Skłodowska, Sect. C, 7, 8: 497-539.

26. W ołyńska, M., 1956: Rozwój płodowy nadnercza człowieka. Folia morphol.ıl, $7: 35-51$.

Bialystok Medical Academy,

Department of Histology and Embriology,

Białystok, ul. Kilińskiego 1.

\section{EXPLANATIONS OF PLATES}

\section{Plate IX.}

Fig. 1. Adrenal gland of young male shrew in June. Three zones of the cortex caran be seen. Magn. $280 \times$.

Fig. 2. Adrenal gland of young male. Zona glomerulosa and zona fasciculata caran be seen. Magn. $580 \times$.

Fig. 3. Adrenal gland of young male. Small cells with dense, acidophilic cytoplasnm can be seen between zona fasciculata and zona reticularis. Magn. $580 \times$.

Fig. 4. Adrenal gland of young male. Zone fasciculata can be seen in the upper parirt of the photograph, and the external part of zona reticularis in the bottomm part. Magn. $580 \times$.

\section{Plate X.}

Fig. 1. Adrenal gland of young male in January. Magn. $280 \times$.

Fig. 2. Adrenal gland of old adult male in April. Dark cells of tse internal part oof zona reticularis (fourth layer, zona juxta-medulla) can be seen in the topp part of the photo. In the bottom part - the light-coloured cells of the medulla. Sinus vessels congested with blood. Magn. $580 \times$.

Fig. 3. Adrenal gland of pregnant female. Cells of the internal part of zona reticult1aris can be seen on the right side, and cells of the medulla on the ieftet. Magn. $580 \times$.

\section{STRESZCZENIE}

Autorka przebadała 138 nadnerczy ryjówki aksamitnej, Sorex araneus L in nate us, 1758. Ryjówki łowione były na terenie Białowieskiego Parku Narodowegoo. Nadnercza utrwalano w płynie Bouina i formalinie, zatapiano w parafinie, krajanao i barwiono Azanem, metodą Massona i hematoksyliną i eozyną.

Autorka stwierdziła, że kora nadnerczy zarówno samców jak i samic składa sicię z trzech warstw: kłębkowatej (łukowatej), pasmowatej i siateczkowej. Najgrubszzą warstwą jest warstwa siateczkowata. Od pażdziernika następuje inwolucja koryy, a $w$ miesiącach zimowych jest ona najcieńsza. Inwolucji ulega warstwa pasmowatta i siateczkowata, warstwa kłębkowa przez cały czas pozostaje bez zmian. Grubośść warstwy pasmowatej i siateczkowatej wzrasta u przezimków na wiosnę, nieznacznitie u samców, bardzo silnie u samic. Osiąga ona w tej grupie taką samą grubość jahk u osobników młodych.

U samiczek kotnych oraz karmiących i równocześnie kotnych obserwuje się przeerost warstwy siateczkowatej.

Część wewnętrzna warstwy siateczkowanej - warstwa juxta-medularna wystęępuje u młodych samców. W zimie część ta ulega zanikowi i ponownie spotyka sidę ja. w kwietniu u samców dojrzałych płciowo. U miodych samiczek brak tej warstwyy, natomiast wyraźnie występuje ona u samiczek kotnych oraz kotnych i karmiącychh. 

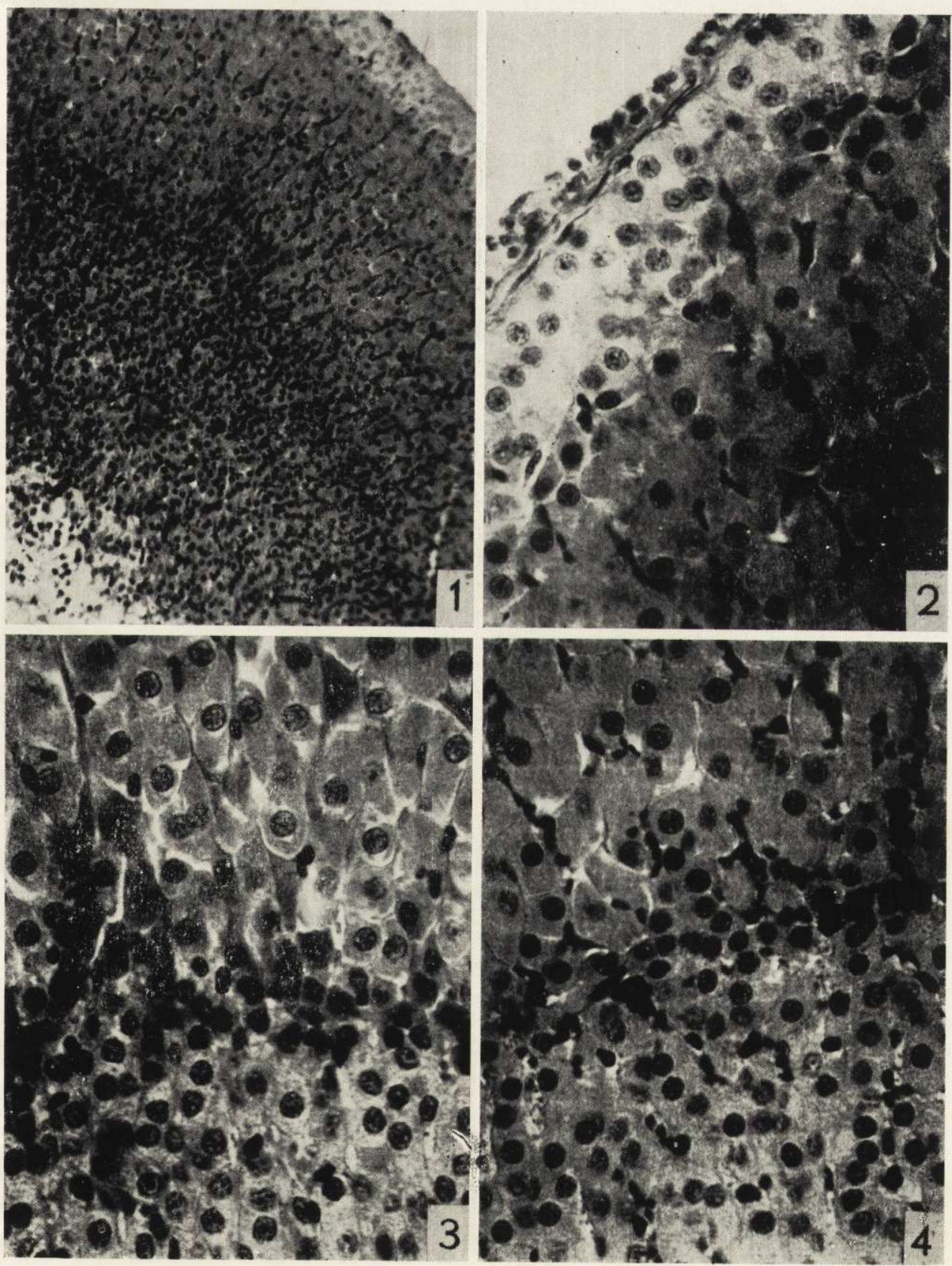

S. Siuda

auctor phot. 
ACTA THERIOLOGICA Vol. VIII, 7.

Plate X.
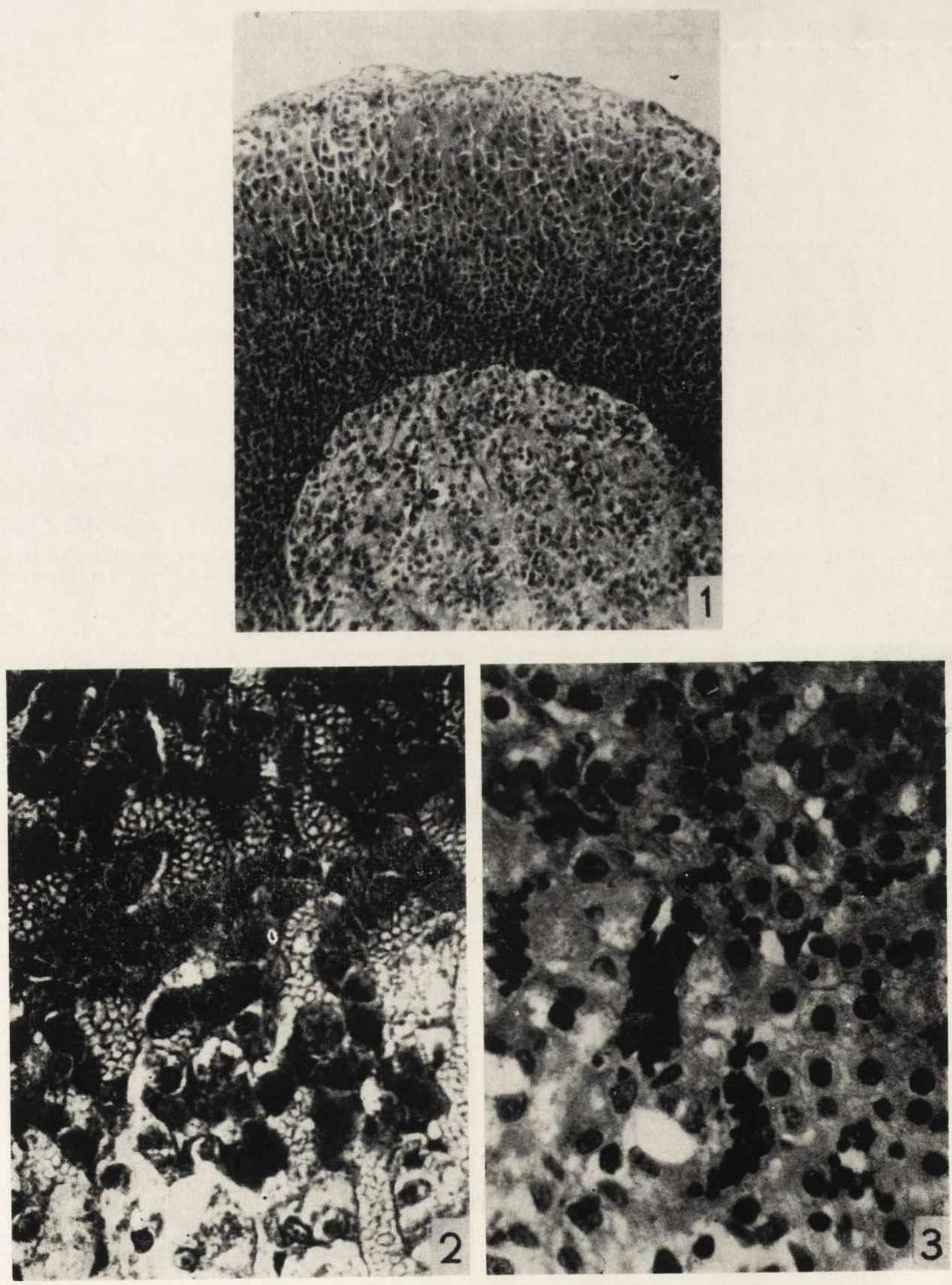

s. Siude

auctor phot. 